\title{
THE AMBIGUITY OF CAPACITY: A REJOINDER TO TREVOR HART
}

\author{
Stephen Andrews
}

\section{Summary}

This brief rejoinder challenges Trevor Hart's suggestion that Karl Barth may have misunderstood Emil Brunner's notion of 'a point of contact', and rejects the claim that Barth's own theology requires a positing of human 'capacity', defined in a passive sense. The essay begins by sketching the broader context of the BarthBrunner debate, which makes the proposal of mutual misunderstanding between the two less likely. The second section explores Hart's concept of 'capacity', and seeks to show that this is incompatible with Barth's theology. An exposition of Barth's doctrine of the incarnation forms the third part of the essay, and is an attempt to demonstrate that what stood at the heart of the debate from Barth's point of view was divine freedom. Then the rejoinder concludes with a rarely cited account of Barth's attempt at personal reconciliation with Brunner.

In 1975, John Macquarrie bemoaned the fact that Christians have a weak theology of nature. ${ }^{1}$ The intervening eighteen years has produced some work of merit in this area, notably at the hands of Wolfhart Pannenberg and Eberhard Jungel, but I doubt whether Macquarrie's opinion today would be very different from what it was then. It is for this reason that I welcomed the article by Trevor Hart in the last issue of the Tyndale Bulletin (44 [1993] 289-305), entitled, 'A Capacity for Ambiguity?: The Barth - Brunner Debate Revisited'. In this clearly and engagingly written essay, Hart offers a useful introduction to and exposition of the 1934 debate between Karl Barth and Emil Brunner over the matter of natural theology. Of

\footnotetext{
${ }^{1}$ Macquarrie wrote: 'Daniel Day Williams often used to say that most Christian theology of the past few decades lacks any account of Nature. Unquestionably, there is justice in this charge'. ('The Idea of a Theology of Nature', Union Seminary Quarterly Review 30 [1975] 69-75 [p. 69]).
} 
particular interest was Hart's attempt to relate the controversy to the exigencies of Germany in the pre-war period, ${ }^{2}$ as well as his reconsideration of Brunner's concepts of a 'point of contact' and the human 'capacities' for revelation and speech. In my estimation, the chief contribution Hart makes to the discussion is his contention that Barth either misunderstood Brunner or, what he seems to think is more likely, that Barth was inconsistent in his own theological reasoning. Hart argues that when this inconsistency is explored, we find that there may be room for a natural theology in Barth's system after all. Barth was, of course, capable of missing Brunner's meaning and of lapses in his own theology. But the view being offered in this rejoinder is that Barth almost certainly did not misunderstand Brunner, and that his theological inconsistencies, if such they were, cannot be so easily resolved as Hart supposes.

\section{The Context of the Debate}

Hart's paper begins with a description of the political setting in which Barth and Brunner clashed. He rightly points out that what was at stake for Barth was more than a matter of fine tuning an obscure point of doctrine. The ominous advance of German Nationalism unavoidably raised the question of whether it was possible for human beings to come to any kind of right understanding about God through nature and reason alone. But it was not the threat of fascism which initially led Barth to a rejection of any notion of natural theology. While this context may well have lent a certain urgency, and, indeed, hostility to the discussion, as Hart indicates, it does not adequately describe the background of the debate. Hart does acknowledge that this debate 'murmured on for some considerable time' before 1934, and 'was continued with no small amount of enthusiasm long afterwards' (p. 289), but it may be that he does not take the length of their controversy sufficiently into account in his analysis. I think that if he did, it

2This is a feature also of interest to Stephen $\mathrm{H}$. Webb, Re-figuring Theology: The Rhetoric of Karl Barth (SUNY Series in Rhetoric and Theology; New York, 1991) 199, n. 34. 
would be harder to believe that Barth actually misunderstood Brunner.

Hart observes that until 1934, Brunner and Barth were both regarded as soldiers from the same theological camp, and that Brunner himself was surprised by Barth's vituperative opposition in that same year. But there was already evidence of a potential rift between the two ten years earlier. This can be discerned in Barth's not wholly favourable review of Brunner's treatment of Schleiermacher, which appeared in $1924 .{ }^{3}$ Writing in 1968, Barth was to say that it was in this review that there appeared 'some first indications of my later conflict with Brunner'.4

In about 1929, Brunner began to propagate his natural theology and 'point of contact' (Anknüpfungspunkt). This made Barth uneasy and he privately sought to clarify his own position in relation to Brunner. The seriousness of their differences is evident in that by 1930, Barth could already say that he and Brunner had 'discussed so much together and yet had agreed so little over fundamentals'. ${ }^{5}$ In 1932, Barth published his Prolegomena to Church Dogmatics, in which he publicly rebutted Brunner's argument for a 'point of contact'. 6

Then came the celebrated collision between the two titans in 1934 when Brunner, in an apparent attempt to salvage his relationship with Barth and to reaffirm their essential theological oneness, published his tract, Nature and Grace: a

\footnotetext{
3Brunner's work was titled, Die Mystik und das Wort (2nd ed.; Tübingen, 1928), and Barth's review, 'Brunners Schleiermacherbuch', appeared in the journal Zwischen den Zeiten 8 (1924) 49-64.

4'Nachwort', in Schleiermacher-Auswahl, 296-97 (quoted in Eberhard Busch, Karl Barth: His life from letters and autobiographical texts [trans. John Bowden; London, 1976] 152).

${ }^{5}$ Briefwechsel Karl Barth - Rudolf Bultmann, 1922-1966, 118; quoted in Busch, Karl Barth, 207.

6Barth wrote: 'Man's capacity for God, however it may be with his humanity and personality, has really been lost. [...] The image of God in man [...] which constitutes the real point of contact for the Word of God, is the one awakened through Christ from real death to life and so "restored", the newly created rectitudo now real as man's possibility for the Word of God. This point of contact is, therefore, not real outside faith but only in faith'. (Church Dogmatics, I/1 [trans. G.W. Bromiley; Edinburgh, 1975; German 1936] 273).
} 
contribution to the discussion with Karl Barth. But this was greeted by Barth's shot-across-the-bow response, No! Answer to Emil Brunner. As Hart's essay indicates, both positions get a good airing. However, while both Brunner and Barth maintained that they had been misunderstood by the other, it is instructive to note that Brunner's second edition of Nature and Grace, which he published in the following year, did not change Barth's opinion. Barth and Brunner continued the debate in subsequent writing and in private discussion, and despite the fact that both to some extent reformulated their positions, agreement was not reached. 7 There was even an attempt in 1960 (when Barth was 74) to bring the two together for reconciliation, but disappointingly, this did not work out. 8 So how, we wonder, could so many words be exchanged over the course of thirty years and yet the differences between them still be regarded as a misunderstanding?

There is on the one hand, of course, the possibility that Barth had made up his mind about Brunner for reasons which were tenuous, and that he was not open to a change of opinion. While such personal prejudice would be difficult to prove, we do know that Barth carried with him a deep suspicion of English theology as being too Pelagian, and that Brunner had spent time in Britain and the United States. ${ }^{9}$ Did Barth think

7Joan E. O'Donovan notes in her article, 'Man in the Image of God: The Disagreement between Barth and Brunner Reconsidered' (Scottish Journal of Theology 39 [1986] 433-59) how, in his work Man In Revolt (trans. Olive Wyon; London, 1939; German 1937), Brunner abandoned formal and material terminology in favour of 'the-humanity-of-the-sinner' and its 'dialectical relation' to the 'Imago-origin'. She notes too how in his reply to Barth in 1951 (in 'The New Barth: Observations on Karl Barth's Doctrine of Man', SJT 4 [1951] 123-35), Brunner affirms that the imago Dei is an analogia relationis. On the other hand, Urs von Balthasar thinks that in the later Barth 'there seems to be room for the analogia entis after all' (Karl Barth, Darstellung und Deutung seiner Theologie [4th ed.; Einsiedeln, 1976] 177; ET 137). If von Balthasar's intuition is correct, it should be pointed out that this is so not because of a change in Barth's anthropology (as Hart seems to suggest), but rather a change in his theology.

${ }^{8}$ Busch, Karl Barth, 449.

${ }^{9}$ Busch writes that Brunner 'had a quite characteristic emphasis of his own as a result of a lengthy stay in England'. (Karl Barth, 151) Brunner had also studied at Union Theological Seminary in New York in 1919-20. 
Brunner had imbibed a Pelagian tendency? Once, in personal conversation with John Williams, Barth remarked, 'For Brunner man is neutral: man can sin because man is free. For me man is not neutral: he can only obey.' 10

On the other hand, perhaps Barth's assessment of Brunner was not all that unfair or wide of the mark. It may be noteworthy that in 1936 we find Brunner promoting the work of the Oxford Group, a movement built upon, among other things, the conviction that a set of moral standards stood at the heart of Christianity, and that the transformation of society depended on the pursuit of absolute purity, unselfishness, honesty and love. Barth found the crusade pernicious, claiming, 'One decisive point against it is that while it sets out to be a renewal of Christianity, it fails to respect its mystery, the freedom of grace and the sanctity of the name of God. Instead, all along the line, with all kinds of excuses and changes of terminology, it is turned into humanity and morality'.11 In this respect, Buchmanism might be regarded as a social expression of Brunner's natural theology and as a prime example of why Barth distrusted Brunner's 'point of contact'.

\section{The Issue of Mächtigkeit}

We move now from a consideration of the broader context of Barth's debate with Brunner to some of the particular features of Barth's theology which informed his understanding of anthropology. Two-thirds of Hart's essay is devoted to a helpful summary of Brunner's and Barth's positions, so it is unnecessary here to develop these views further, except in so far as Barth's thinking has been challenged by Hart. For in his summary section, entitled 'Some questions concerning capacity', Hart declares that his chief interest is 'to tease out a possible point of view (possibly Brunner's own) which Barth's

10Recorded in Williams's dissertation, The Doctrine of the Imago Dei in Contemporary Theology: A study in Karl Barth, Emil Brunner, Reinhold Niebuhr and Paul Tillich (Doctoral Dissertation Series Publication Number 10,808; Ann Arbor, 1954) 159.

11'Church or Group?', Evangelische Theologie (1936) 205ff.; quoted in Busch, Karl Barth, 276. 
criticism manifestly falls short of, and which he himself [...] cannot ultimately avoid conceding' (p. 302). In the end, Hart claims to have shown that 'as long as [Barth] adheres to a doctrine of the incarnation, or to a belief that God has revealed himself to humans, [he cannot] avoid positing a point of contact' in a carefully qualified sense. We want to ask, what is this qualified sense, and would Barth have capitulated to it?

Here Hart focuses on the suffix -mächtigkeit, translated 'capacity', which is an essential component in the debated terms Offenbarungsmächtigkeit ('capacity for revelation') and Wortmächtigkeit ('capacity for speech').12 He exploits an ambiguity inherent in the word and suggests that we think of it in passive rather than active terms. Human beings, he contends, while not having a material capacity or aptitude for revelation, nevertheless have a formal capacity, or perhaps more obliquely, the 'capacity to receive the capacity' for revelation (p. 303-04). Hart cites the examples of the Virgin's womb and the corpse of Jesus, neither of which have the potential in and of themselves to do what they end up doinggiving birth and coming back to life, respectively-but which Hart believes are somehow appropriate instruments of the incarnation and the resurrection. Thus, using Hart's images, Mary and Jesus were suitable objects of divine grace in a way that a slab of granite and a rosebush are not, and it is this suitability to which Hart alleges Barth would have to accede as a 'point of contact'.

${ }^{12}$ Hart takes John Baillie to task perhaps a bit unfairly on p. 302. It was Brunner who, in the Preface to his second edition of Natur und Gnade, complained that Barth read too much into his term, 'capacity for revelation' (pp. v, 57). Baillie merely points out the kinship between speaking and revealing and thus anticipates the point Hart makes on pp. 302-03. It should be mentioned that the terms Ansprechbarkeit, Wortempfänglichkeit and Verantwortlichkeit were also central to this aspect of the discussion. Incidentally, it is curious to me that the suffix -mächtigkeit is never translated 'potential', which would seem to be the term's more appropriate meaning. German does have a modifier meaning 'capacity', namely,-fähigkeit, which both Brunner and Barth appear to use on occasion as a synonym of -mächtigkeit (see esp. Natur und Gnade [Tübingen, 1935] 45). 
The ambiguity of 'capacity' is worth pondering, since it does raise some theologically significant issues, particularly with regard to matters of being and acting in the world. ${ }^{13}$ But I do not think that in the end Hart's elucidation of it would have won any more admiration from Barth than did Brunner's position, a position which Hart's interpretation approaches. ${ }^{14}$ True, Hart did try to 'shift' Brunner's 'point of contact' back a logical step by thinking of 'capacity' as 'the capacity to receive a capacity'. But Barth might have said that in Hart's definition, 'capacity' is either indistinguishable from the humanum, or that it is really part of the human material being, as any attempt to distinguish it from the humanum will readily show. Hart's use of Mary as an illustration does not help to prove his case, since as soon as we begin to talk about the womanhood of Mary as distinct from the woman Mary, we are talking about qualities which in some sense cooperate with the grace of God. Hart recognises this implicitly when he writes that Mary's womanhood 'must be deemed significant' in God's choosing of her.

Clearly for Barth this will not do. It is as if the terms of God's action in the world are set by fallen factors outside his control, and this threatens what is really at stake for Barth in this whole debate: the freedom of God. This is plainly what Barth seeks to defend when he writes:

If, nevertheless, there is an encounter (Begegnung) and communion (Gemeinschaft) between God and man, then God himself must have created for it conditions (Voraussetzung)

\footnotetext{
${ }^{13}$ Barth would undoubtedly agree that the concept of human capacity has important ontological and ethical implications. But these implications are largely sociological, since for him the imago Dei expressed itself in the human capacity for interrelationship and community.

14Baillie's reading of Brunner would seem to suggest that Hart and Brunner have a common understanding of 'capacity', which allegedly meant 'the purely passive capacity to be reached by the revelation and to hear the Word when it is uttered'. (Natural Theology [London, 1946] 9). Compare with Brunner's clarification on the subject of human beings receiving the Word of God: 'this "receptivity" (Empfänglichkeit)-must not be understood in the material sense. This receptivity says nothing as to his acceptance or rejection of the Word of God. It is the purely formal possibility of his being addressed (Ansprechbarkeit).' (Natur und Gnade, 18; ET p. 31).
} 
which are not in the least supplied (not even 'somehow', not even 'to some extent'!) by the existence of the formal factor.

And again:

The fact that God 'reaches' man with his Word may well be due to something other than the formal possibility of his being addressed and his humanitas. (Nein!, p. 26; ET 89)

We see that Barth does not deny the existence of the humanum; just that it exists as a precondition of grace. And if the humanum itself cannot qualify as a 'point of contact', it is difficult to see how Hart's notion of 'capacity' can avoid the charge of being a precondition.

Is Barth being illogical here? Hart thinks that as long as Barth adheres to a doctrine of the incarnation, he cannot escape positing a formal capacity in human beings to receive divine revelation. But this is not the case when one considers the radical nature of Barth's doctrine of the incarnation, which for him is 'the great Christian mystery and sacrament, besides which, strictly speaking, there is no other' ${ }^{15}$ In order to clarify the issues, it might be helpful briefly to explain what Barth understood by incarnation and, by implication, the imago Dei (and here it is essential to refer to Barth's later writing).

\section{The Incarnation and Barth's Anthropology}

When one considers the statement 'God became a human being in the person of Jesus Christ', where is the most appropriate place to start? Is it not reasonable to begin with what it means to be 'human'? Not according to Barth. For him, anthropology begins not with Adam, but with Jesus Christ. For the incarnation means that 'God the Son assumed a concrete possibility of human being and essence prepared and elected by him for this purpose, thereby conferring actuality on it by making himself its actuality'. ${ }^{16}$ Moreover, it is in this action 'by

${ }^{15}$ Church Dogmatics, IV/2 (trans. G.W. Bromiley; Edinburgh, 1958; German 1955) 42.

${ }^{16}$ Church Dogmatics, IV/2, p. 53. 
him and in him [that] the divine receives a determination to the human, and the human receives a determination from the divine'.17 The incarnation is a divinely chosen and effected contingency. In other words, there is nothing in humanity which in any way merited, invited or even exhibited an openness to the incarnation. These qualities are generated by the incarnation itself which, in the event, constitutes the human being. Any qualitative substance is imparted by the incarnation, and hence, any qualitative analysis must be approached through the incarnation. As Robert Willis comments, 'It is clear from this that the incarnation, and the determination of the human resulting from it, cannot be viewed in any sense as an immanent possibility of the created order'. ${ }^{18}$

What, then, are we to make of the imago Dei, with which Adam was bestowed at creation? Is this not a kind of quality which, like Hart's 'capacity', might warrant divine action on behalf of human beings? Once again, not necessarily. For Barth, the imago Dei refers not to Adam's creation as a being with the capacity to relate to God, but to that capacity of relationship within God himself, a capacity revealed, demonstrated and actualised in Jesus Christ. Barth prefers not to discuss anthropology in terms of what humanity is $b y$ creation, since the created order is fallen. As he explained in 1952, 'Our human nature is preserved by sharing Adam's nature, because Adam's humanity is a provisional copy [Barth's emphasis] of the real humanity that is in Christ'.19

${ }^{17}$ Church Dogmatics, IV/2, p. 75.

${ }^{18}$ The Ethics of Karl Barth (Leiden, 1971) 141.

${ }^{19}$ Christ and Adam: Man and Humanity in Romans 5 (trans. T.A. Smail) Scottish Journal of Theology Occasional Papers 5 (1956) 10. For this reason, it is dangerous in Barth's estimation to think too literally about Christ's human nature, for 'it is entirely too easy to read out of the word "nature" a reference to a generally known or at least conceivable disposition of being, so that by the concept of a "divine nature" we are led to think of a generally known, or knowable essence of deity, and by that of "human nature" to a generally known or at least knowable essence of man, and so-what at present is our concern-what is to be understood by the humanity of Jesus Christ is determined by some sort of universal anthropology, a doctrine of man in general and as such.' (Church Dogmatics, IV/2, pp. 26-27). 
Consequently, the humanum cannot be described or given any kind of status outside the event of the incarnation. Likewise, any response to God, like faith, responsibility, and even sin, can only be regarded as a mystery. Faith and responsibility are conceived of 'as a sheer miracle which can in no sense be [the human being's] direct possession, but which can only be received as [...] given to him in the action of the Holy Spirit', to quote Willis once again. ${ }^{20}$ And as for sin, it is worth hearing further from Barth in his conversation with Williams, cited above: 'One cannot explain sin: it is an actuality with possibility.'21

It is because of Barth's jealousy for God's otherness, for the purity and independence of his grace, in short, for the freedom of God, that I doubt he would have had much sympathy with Hart's proposal for a 'point of contact' in the human 'capacity to receive a capacity'. True, Barth's jealousy on this point has often led to the charge that he was a monist, and that his attempt to define the human person with 'the actuality of God's decision, made in, through, and for the sake of his Son' (using O'Donovan's phrase), has made it difficult at least to distinguish between God and man, and between Creator and creation.22 This is not the place to explore the adequacy of Barth's christology, but we should observe that for all of his emphasis on the divine initiative in Christ, there is still room in Barth's theology to talk of human 'capacity' and a 'point of contact'. However, this discussion cannot take place on the basis of human models of interaction, but rather on the basis of relationships within the Trinity. The imago Dei was for Barth (and later on for Brunner as well) an analogia relationis; an analogia, that is, corresponding to the inner Trinitarian being. Human 'capacity' described in any other terms would therefore be regarded by Barth as an example of hubris and idolatry.

${ }^{20}$ The Ethics of Karl Barth, 269.

21The Doctrine of the Imago Dei in Contemporary Theology, 159.

${ }^{22}$ 'Man in the Image of God', 456. For this reason Willis finds Barth's anthropology wanting: "There does indeed appear to be operative in Barth's anthropology, if not a final or irremediable "absorption" of the human, at least a serious ambiguity about its status.' The Ethics of Karl Barth, 240. 


\section{The last words Brunner ever heard}

It is no wonder that with so much at stake, both in the political context of Germany in the 1930s and within the whole scheme of Barth's and Brunner's theologies, this debate took a heavy toll on their friendship. To some it must have seemed as though Barth was not only refuting any 'point of contact' in humanity in general, but also refusing any 'point of contact' with Brunner himself. However, in Busch's biography of Karl Barth, there is a poignant story about Barth's personal reconciliation with Brunner on the eve of Brunner's death. Brunner died in 1966, but shortly beforehand Barth had sent him the following message through a friend: 'If he is still alive and it is possible, tell him again, "Commended to our God", even by me. And tell him, Yes, that the time when I thought that I had to say "No" to him is now long past, since we all live only by virtue of the fact that a great and merciful God says his gracious Yes to all of us.'23 Using Brunner's own metaphor of a soldier on sentry duty, Hart concludes that Barth's sniping was unwarranted and undeserved, since Brunner may have given a legitimate password after all. But clearly, unless his gesture is a purely sentimental one, Barth believes that the password is to be found neither in Brunner's 'point of contact', nor even in his own vehement rebuttal, but finally and only in the divine affirmation.

${ }^{23}$ Message sent through Peter Vogelsanger; recounted in Busch, Karl Barth, 476-77. 